\title{
Trends and gaps in the global scientific literature about Jatropha curcas L. (Euphorbiaceae), a tropical plant of economic importance
}

\section{Tendências e lacunas na literatura científica global sobre Jatropha curcas L. (Euphorbiaceae), uma planta tropical de importância econômica}

\author{
Illana Reis Pereira'; Patrícia Lima D'Abadia²; \\ Angélica Daiane Lemos do Prado ${ }^{1}$; Fabio Santos Matos ${ }^{3}$; \\ João Carlos Nabout ${ }^{4}$; Pablo José Gonçalves ${ }^{5}$; Luciane Madureira Almeida ${ }^{4 *}$
}

\begin{abstract}
Jatropha curcas L., popularly known as the physic nut, is a monoecious, perennial lactiferous species belonging to the family Euphorbiaceae. Recently, interest in this species has been growing, due to its ability to flourish on degraded land and in soils with low natural fertility, the high oil content of its seeds, its rapid growth and easy propagation, and the identification of several secondary metabolites with medicinal importance. This study aims to report the main trends and gaps in the global scientific literature about $J$. curcas L, using a scientometric analysis. We have carried out this scientometric analysis on the global literature to identify: 1) temporal publication trends; 2) the quality of scientific production, estimated using citation numbers and journal impact factors; 3 ) the main journals and countries interested in this topic and the language of scientific divulgation; 4) the main research fields; 5) the use of wild or commercial cultivars; and 6) average authorship levels and international collaboration networks. Our findings have revealed a continuous increase in both quantitative and qualitative parameters in studies about $J$. curcas. The main trends in physic nut studies involve biofuel production and the plant's agronomic characteristics. The main knowledge gaps relating to J. curcas are in the fields of forestry, sustainability, animal nutrition, and genetic improvement. Another problem identified in this study is a lack of commercial seeds; none of the studies analyzed have used commercial seeds. India, Brazil, and China together are responsible for $55 \%$ of the knowledge about this species, obtained through scientific production. Only moderate international collaboration has been observed between countries, perhaps as consequence of conflicts of interest. Despite an increasing number of articles, some countries have stopped producing $J$. curcas L, and the worldwide crop production has decreased.
\end{abstract}

Key words: Biofuel. Pharmacological potential. Oilseed. Scientometrics.

\section{Resumo}

Jatropha curcas L., p opularmente conhecida como pinhão manso é uma espécie monóica, lactífera

${ }^{1}$ Discentes de Mestrado, Programa de Pós-Graduação em Produção Vegetal, Universidade Estadual de Goiás, Câmpus Ipameri, UEG, Ipameri, GO, Brasil. E-mail: illanareis@hotmail.com; pradoadl@hotmail.com

${ }^{2}$ Discente de Doutorado, Programa de Pós-Graduação em Recursos Naturais do Cerrado, Câmpus Anápolis de Ciências Exatas e Tecnológicas, Henrique Santillo, UEG, Anápolis, GO, Brasil. E-mail: patricialima.bio@gmail.com

${ }^{3}$ Prof., Universidade Estadual de Goiás, Câmpus Ipameri, UEG, Ipameri, GO, Brasil. E-mail: fabio.matos@ueg.br

${ }^{4}$ Profs., UEG, Câmpus Anápolis de Ciências Exatas e Tecnológicas, Henrique Santillo, UEG, Anápolis, GO, Brasil. E-mail: jcnabout@gmail.com; luciane.almeida@ueg.br

Prof., UFG, Instituto de Física, Goiânia, GO, Brasil. E-mail: pablo@ufg.br

* Author for correpondence 
e perene pertencente à família Euphorbiaceae. Recentemente, o interesse científico por esta espécie vem aumentando devido à capacidade dessa planta de se desenvolver em terras degradadas ou em solos de baixa fertilidade natural; ao alto teor de óleo de suas sementes; a propagação fácil; ao rápido crescimento; a identificação de vários metabólitos secundários com relevante potencial medicinal. O objetivo deste estudo foi relatar as principais tendências e lacunas da literatura científica mundial sobre $J$. curcas L através de uma análise cienciométrica. Neste estudo foi realizada uma análise da literatura mundial tentando identificar: 1.) as tendências temporais de publicação; 2.) a qualidade da produção científica estimada pelo número de citações e fator de impacto das revistas; 3.) as principais revistas e países interessados no tema ea linguagem da divulgação científica; 4.) os principais campos de estudos; 5.) A utilização de cultivar selvagem ou comercial; e 6.) número médio de autores e rede de colaboração. Como resultado, observou-se aumento contínuo em ambos os parâmetros quantitativos e qualitativos nos estudos sobre $J$. curcas. As principais tendências em estudos de pinhão-manso foram à produção de biocombustíveis e características agronômicas. As principais lacunas no conhecimento sobre $J$. curcas foram associados com a silvicultura e sustentabilidade, nutrição animal e melhoramento genético. Outro problema identificado neste estudo foi a falta de sementes comerciais, todos os artigos investigados usaram sementes não comerciais. Em relação à produção científica, Índia, Brasil e China juntos foram responsáveis por $55 \%$ dos artigos publicados sobre o tema. Além disso, observou-se moderada colaboração internacional entre os países, talvez como consequência do conflito de interesse. Apesar do aumento no número de artigos sobre J. curcas, alguns países pararam de produzir pinhão manso, e a produção mundial dessa cultura está diminuindo.

Palavras-chave: Biocombustível. Potencial farmacológico. Oleaginosa. Cienciometria.

\section{Introduction}

Jatropha curcas L., popularly known as the physic nut, is a monoecious, perennial lactiferous species belonging to the family Euphorbiaceae (LAVIOLA et al., 2015). According to a recent literature review, many authors consider $J$. curcas to be one of the most promising oilseeds for biofuel production (CONTRAN et al., 2013; DIAS et al., 2012). This assessment of $J$. curcas is based on the following factors: its high oil content, which is easily extracted from seeds, producing 30-35\% of oil per seed dry mass (JONGSCHAAP et al., 2007); its amazing adaptability, which allows it to survive in soils with low natural fertility, even under arid and semi-arid conditions (ACHTEN et al., 2010; CONTRAN et al., 2013); its easy propagation and rapid growth; its hardiness; and multiple uses of the whole plant. This species has already been used in medical applications, for example, as well as in reforestation, animal feed, and soap production. Among these different uses, attention has recently focused on its potential pharmaceutical value (SHAHINUZZAMAN et al., 2016; SHARMA et al., 2016; THOMAS et al., 2008), as its leaves, fruit, latex, and bark contain glycosides, tannins, phytosterols, flavonoids, and steroidal sapogenins with wide-ranging medicinal properties (DEBNATH; BISEN, 2008).

Given the great economic potential of J.curcas, the Global Exchange for Social Investment (GEXSI) estimated in 2008 that worldwide production of this cultivar would reach 12.8 million hectares by 2015 (DEVAPPA et al., 2012). However, despite that predicted rapid increase in production, $J$. curcas remains a wild, undomesticated plant that shows considerable performance variability, which makes its cultivation a risky business (ACHTEN et al., 2010; BEHERA et al., 2010). In fact, there are significant concerns about methods of cultivating this species to maximize its potential. Very little is known about the biological, ecological, or biochemical character of this plant.

The present study focuses on reporting the main trends and gaps in the global scientific literature about $J$. curcas, using a scientometric analysis. Scientometry (literally: measurement of science) is a scientific field that examines the development, structure, productivity, and interconnectivity of scientific work (MUND et al., 2014). Examples 
of scientometric instruments include quantitative and qualitative analyses of articles published in a given field of scientific research. This scientometric study aims to identify the main areas of scientific investigation of physic nut species. To achieve this, we have analyzed papers published in peerreviewed scientific journals over the last 24 years. The bibliometric analysis has evaluated: 1) the temporal publication trends; 2) the quality of scientific production, estimated using the number of citations and the impact factors of journals; 3) the main journals and countries interested in the theme, and the language of scientific discourse; 4) the main fields of study; 5) the use of native or commercial cultivars; 6) average authorship levels and international collaboration networks. Curiously, our analysis has shown that the level of scientific interest in $J$. curcas L is very different from the actual business reality. While the number of articles about $J$. curcas L continues to increase, worldwide crop production is decreasing.

\section{Material and Methods}

\section{Data source}

Data were retrieved from the Thomson Reuters (ISI) Web of Knowledge. We chose this database because it has long been recognized as the most authoritative scientific and technical literatureindexing tool available, providing data on the most important areas in science and technology research. Data analysis was restricted to articles published between 1991 and 2015; data entries from 2016 were excluded from the analysis because this year's acquisition was not complete; pre-1991 data were not considered because no electronic abstracts were available in the ISI database for that period. The impact factor for each journal was obtained using Journal Citations Reports (JCR) for the year 2015.

\section{Search strategies and the analysis of articles}

We used the following words in our search: "Jatropha curcas" OR "physic nut," and searched for papers that contained those words in the title, abstract, or list of keywords. All types of publications were retrieved. For each paper, we identified: 1) the number of articles; 2) the year of publication; 3) the number of citations; 4) the impact factor of the journal; 5) the journal of publication; 6) the language used to describe the article; 7) the article type (review, research article, proceedings, meeting abstract, and others); 8) the number of authors; 9) the geographical origin of all of the authors; 10) the field of the study; and 11) the use of wild or commercial lineages.

\section{Data analysis}

To evaluate the publication tendency, we performed a Pearson correlation between the number of articles and the years in question. A positive $r$ value indicated an increase in the number of articles about physic nuts over the years, while a negative $r$ value indicated a decrease in the number of publications on this theme. The significance value was obtained using the Monte Carlo test with 999 randomizations. We considered significant $P$ values $<0.05$. This analysis was conducted using the R 3.2.2 program (R CORE TEAM, 2013). The impact factor and the number of citations were evaluated using descriptive statistics (e.g. mean and variation coefficients). To analyze the collaboration network, we obtained the nationality of all of the authors for each paper. The binary matrix containing the countries involved in each article was used to calculate the Jaccard index (distance matrix) and to estimate the collaboration network linking the countries. We used igraph packages in the $\mathrm{R}$ program to view the collaboration network (CSARDI; NEPUSZ, 2006).

To carry out a social network analysis, we selected the 25 countries with the largest number of papers, and calculated Jaccard indices among these countries to estimate the collaboration network. The importance of each country was estimated in relation to its degree of centrality (DC). The degree 
of centrality of the country $i$ (DCi) measures the number of links (edges) each country has. The DCi is divided by number of countries, minus one, to calculate the Relative Degree Centrality (RDCi) of country $i$, which is used to evaluate the importance of countries, depicted in different sizes in network graphs (KOSCHÜTZKI; SCHREIBER, 2008).

\section{Results and Discussion}

The initial literature search of various databases identified a total of 2,303 articles published on $J$. curcas L between 1991 and 2015. Of this total, 333 articles were excluded after screening because they were not full research articles; an additional 233 articles were excluded because they did not address the theme. Ultimately, 1,737 articles remained in the search and served as a basis for this research.

A general analysis shows that the number of articles about $J$. curcas L has increased significantly throughout the period of the study $(r=0.691 ; p=$ $0.0001)$. Figure 1 shows that, in the years before
2007 there were few papers published on this species; that number increased quickly in 20102011. There was a decrease in production in 2013 and renewed growth in 2014.

Of the total of 1,737 articles, 1,262 were published during the last five years, indicating that research on this species has recently attracted more attention. This improvement in scientific production may reflect the financial incentives offered by governmental agencies and large corporations in recent years. For example, in Brazil, the National Counsel of Technological and Scientific Development (Conselho Nacional de de Desenvolvimento Científico e Tecnológico$\mathrm{CNPq}$ ) and other scientific foundations launched a special incentive for research involving species with potential for biofuel production. Between 2007 and 2013 there were 9 specific calls from $\mathrm{CNPq}$ to incentivize biofuel research, with more than 25 million dollars invested (MCT/CNP/FNDCT 40/2013; 03/2010; 46/2009; 47/2008; 46/2008; 26/2008; 30/2008; 39/2007 and 31/2007).

Figure 1. Temporal trends in the number of articles published about J. curcas per year between 1991 and 2015.

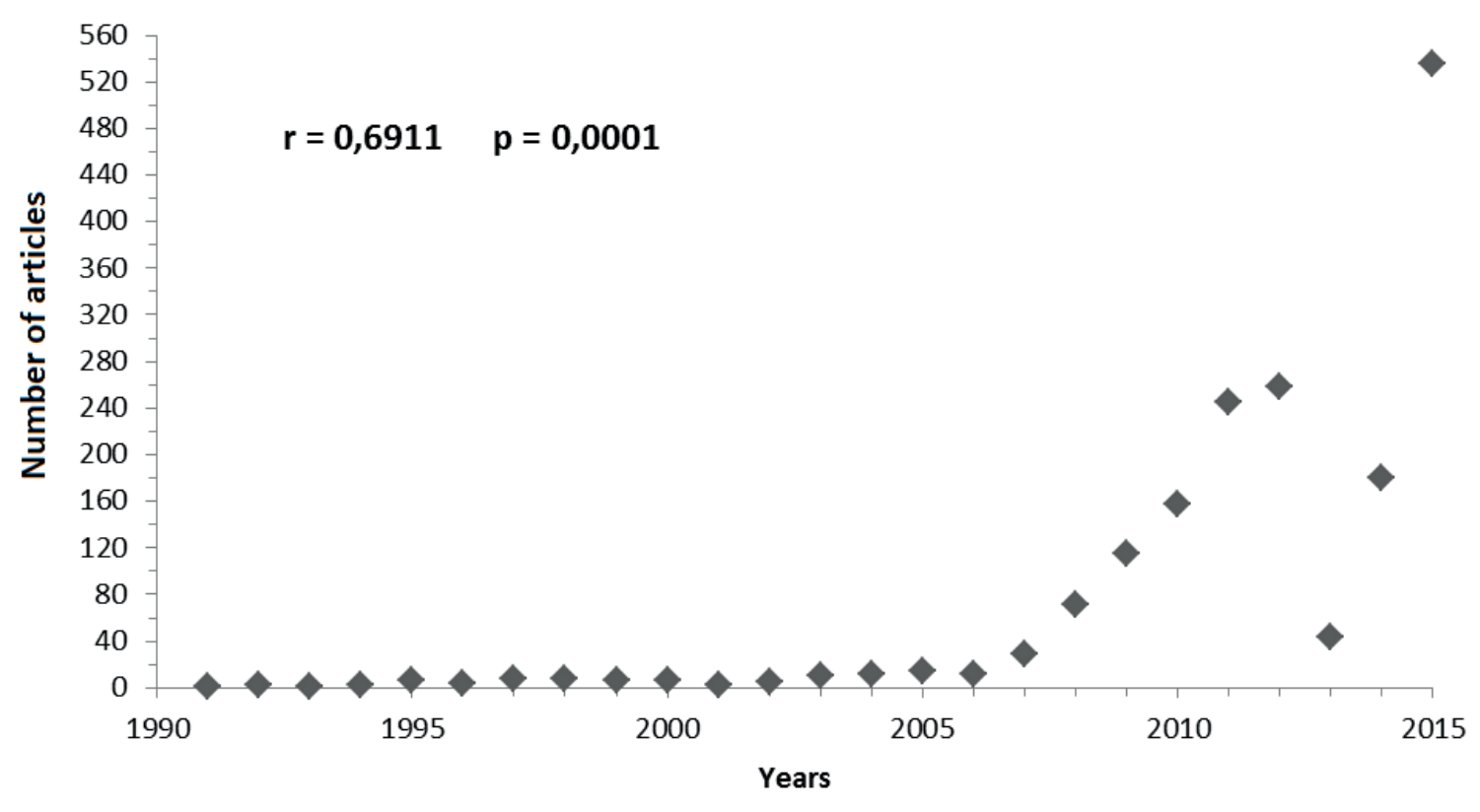


Nowadays, in the scientific community, the number of citations and the impact factors of journals are often used as an indicator of research quality (VITZTHUM et al., 2010). The number of citations shows how many times each publication has been cited within a certain period, while the journal impact factor is calculated using the mean citation rate of all articles published in a particular journal. In the present study, the number of citations ranged from 0-478, with most articles cited between ten and twenty times (Figure 2A). It is known that the number of citations depends on the year of publication and that older papers tend to have more citations (YU; LI, 2007). Thus, we expected the number of citations involving $J$. curcas L to increase over subsequent years, once scientific interest in the species emerged after 2010.

The journals analyzed in this study had impact factors ranging from 0.01 to 21.0 (Figure 2B), with the highest frequency between 0.5 and 1.0. The citation number and impact factor analysis indicated that research on $J$. curcas $\mathrm{L}$ is published in respectable science communication journals. We also analyzed the dissemination of information, based on the choice of written language. Of the 1,737 articles analyzed, 1,610 were written in English, 106 in Portuguese, 11 in Spanish, 4 in French, 3 in Chinese, 2 in Polish and 1 in German. The high number of articles in English make the information easier to spread.

Figure 2. The research quality indicators for $J$. curcas articles, based on number of citations (A), and the impact factor of each journal (B).

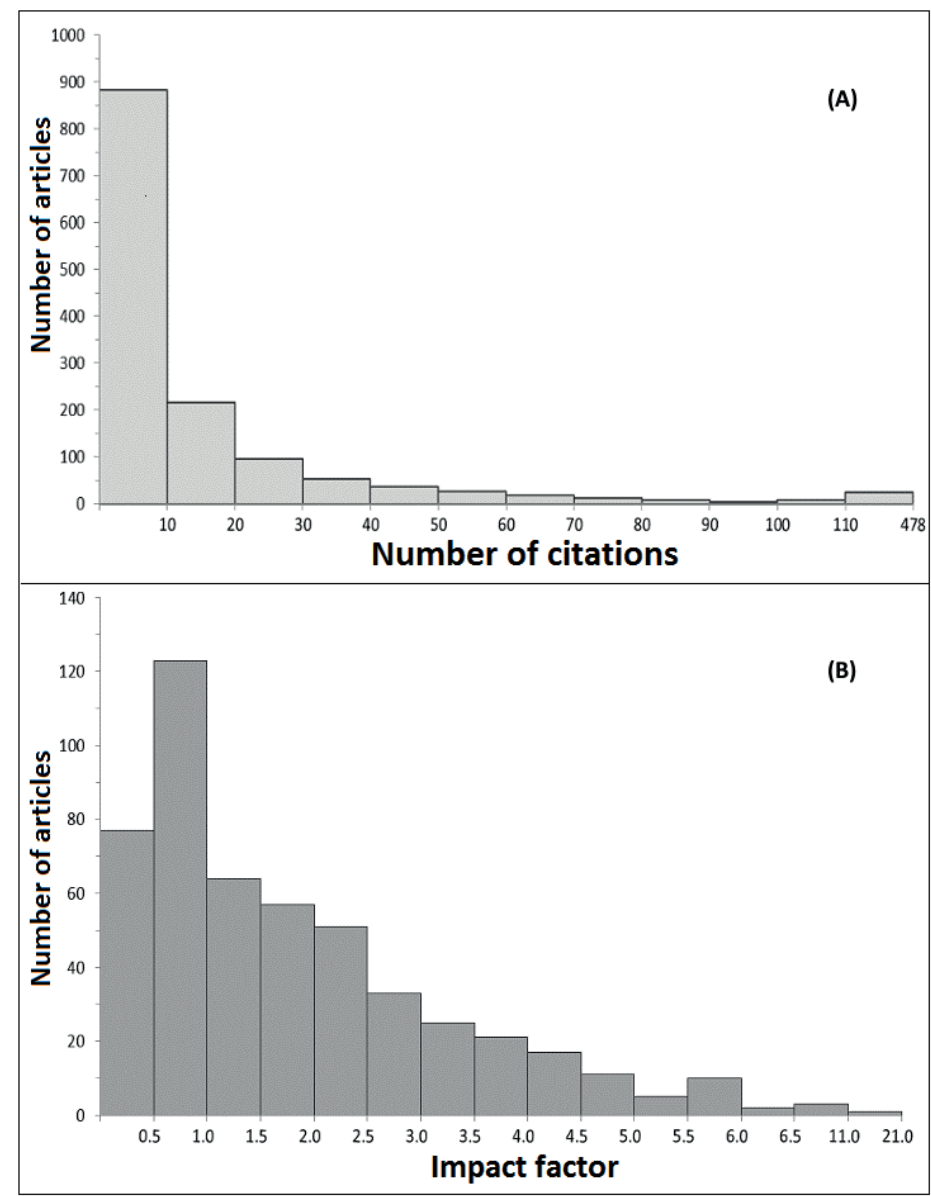


Figure 3 shows journals with more than SeminaCiênciasAgrárias. The majority of these ten published articles. The journal with the journals publish articles that discuss alternatives highest number of publications was Biomass for sustainable energy production, and $J$. curcas $\mathrm{L}$ and Bioenergy with 90 articles, followed by Industrial Crops and Products, Fuel, Bioresource Technology, Energy Conservation Management and appears to be a promising alternative to oil-based energy production. These data confirm the findings on the main areas of knowledge (Figure 3 inset).

Figure 3. The distribution of the number of articles by journal; this graphic shows only journals with more than 10 published articles, and the distribution of articles by knowledge area (inset).

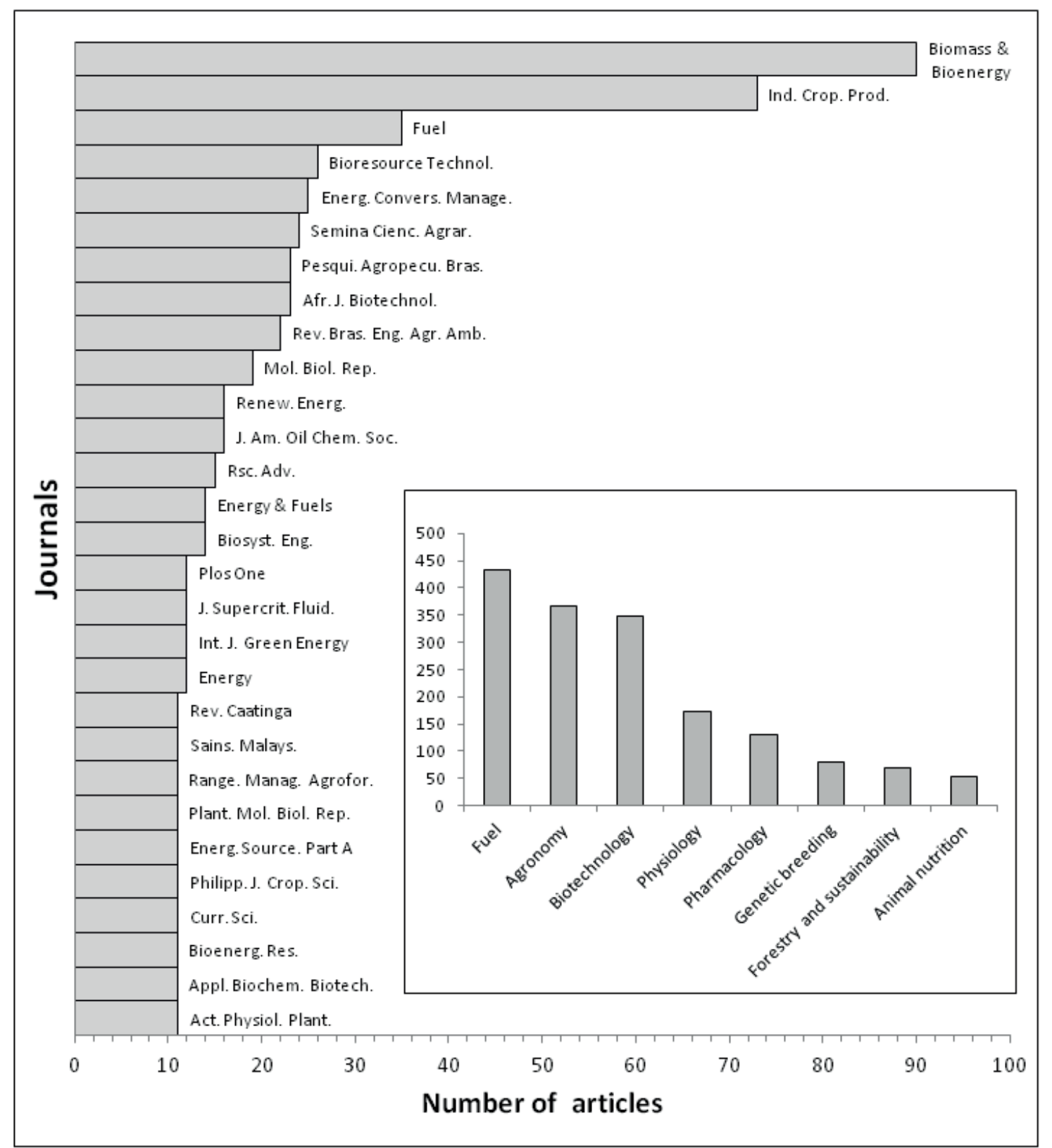


Most of the studies focus on biofuel and agronomy. In these areas, the main reason for investigating $J$. curcas $\mathrm{L}$ appears to be the global need for new renewable energy sources. With the increase in crude oil prices, climate change concerns, and limited reserves of fossil fuel, $J$. curcas L has been growing in importance as the most promising oilseed; it does not compete with edible oil supplies and is different from other species. Moreover, $J$. curcas L oil has higher oxidation stability than soybean seed oil, lower viscosity than castor seed oil, and a lower pour point than palm seed oils (BAILIS; MCCARTHY, 2011). As a non-edible crop-derived oil, J. curcas L is favored for biodiesel production and the trend is expected to continue.

Crude $J$. curcas $\mathrm{L}$ oil is rich in unsaturated oleic and linoleic acids, which make it prone to oxidation and allow it to remain fluid at lower temperatures. $J$. curcas L oil also has a low level of free fatty acids, which improves its storability. Its low sulfur content suggests that the oil will produce less sulfur dioxide when used as a fuel. These characteristics make the oil highly suitable for producing biodiesel (BRITTAINE; LUTALADIO, 2010).

When it comes to economic potential, the market price per ton of $J$. curcas L crude oil (98.5\% purity) is the same as for soybean crude oil ( $99.9 \%$ purity), about US $\$ 360$ (DIAS et al., 2012). Another recent study has shown that biodiesel extracted from $J$. curcas L seeds can produce a kilowatt-hour of electricity at a lower cost than diesel (RAHEMAN; PADHEE, 2016). Despite this economic potential, little is known about $J$. curcas $\mathrm{L}$, and there are a number of challenges to overcome.

The other key objective of this study has been to identify gaps in the knowledge about $J$. curcas L. The inset chart in Figure 3 shows that there are few articles about forestry and sustainability, animal nutrition, or genetic improvement. Our analysis revealed very few articles about the impact of larger plantings of $J$. curcas $\mathrm{L}$ on the environment or its effect on water resources and biodiversity.
In addition, there are very few studies on the reforestation, sustainability, or conservation of this species.

In the field of animal nutrition, some articles report the use of physic nuts as feed ingredient, since the kernel meal left behind after oil extraction is rich in protein (30-32\% total crude protein) and essential amino acids (MAKKAR et al., 1997). However, the presence of toxic compounds can cause death in animals, depending on the quantity of seeds used. Acute doses of $2.5 \mathrm{~g}$ seed kg-1 body weight day ${ }^{-1}$ and chronic doses of $0.025 \mathrm{~g}$ seed $\mathrm{kg}^{-1}$ body weight day ${ }^{-1}$ for 14 days resulted in the death of all the animals (MENDONÇA; LAVIOLA, 2009). It will be interesting to identify nontoxic varieties of $J$. curcas $\mathrm{L}$, in which the seeds can be safely used in animal nutrition, increasing the value of these bioproducts.

There have been few studies on genetic improvements to the main traits of $J$. curcas $\mathrm{L}$ (BHERING et al., 2013; FREITAS et al., 2016; ROCHA et al., 2012; SHABANIMOFRAD et al., 2013), compared to other oilseed crops, such as soybeans, cotton, peanuts, and sunflower seeds (FREITAS et al., 2011). In addition, most studies failed to take into consideration repeated measures or plants at different stages.

Ultimately, J. curcas L production on a large scale will remain an unrealistic goal, unless there is an improvement in its genetic traits. Research on commercial cultivars has revealed a few genetically improved cultivars; in India, we found the following improved cultivar: JCL $\mathrm{Max}_{3}{ }^{\mathrm{TM}}$ Elite HYV, (ACJP proprietary product: www.jatrophabiodiesel.org). We then carried out a search for scientific articles using commercial cultivars, and found that no articles published before 2015 used commercial seeds. This means that all of the previous articles used undomesticated or improved plants, but not commercial cultivars.

The use of wild plants makes it difficult to predict commercial yields, due to their large genetic 
variations and lack of uniformity. There is little knowledge of their reproductive biology and scant information about the interaction of genotype and environment. Thus, there are still serious risks in the decision to plant extensive areas because of the existing unimproved genotypes. For this reason, the selection, breeding, and multiplication of superior genotypes for quality planting material is now the main challenge in achieving domestication and improving productivity. It is desirable to obtain cultivars with a high oil yield and reduced toxicity, ensuring the protection of animals without impairing natural pathogen resistance.

This article has also analyzed the main countries considering J. curcas L production. Figure 4A shows the country of each corresponding author. India publishes the largest number of scientific studies of the physic nut, with 394 articles (22.7\%). The nation with the second largest number of published works is Brazil, with 300 articles (17.3\%). China has 255 articles (14.7\%), and 69 other countries have published 788 articles (45.3\%). According to the Advanced Biofuel Center, India currently has about 630 thousand hectares of Jatropha curcas, and is one of the most advanced countries in the production of this cultivar. The Indian government has invested in various programs of seed distribution to farmers, installed micro-refineries, and purchased production at pre-established prices. The government initiative includes the following objectives: employment, and the local production of a renewable bioenergy source to improve living standards and catalyze the development of the rural non-farm sector. However, there is some doubt as to whether government support will be sustainable in the long term (BRITTAINE; LUTALADIO, 2010).

Figure 4. Analysis of the geographical distribution of authors and the collaboration networks involved in articles about $J$. curcas: A. shows the number of published items per country (using corresponding author data); B. shows the average authorship levels per year; and $\mathbf{C}$ ) shows the international collaboration networks.

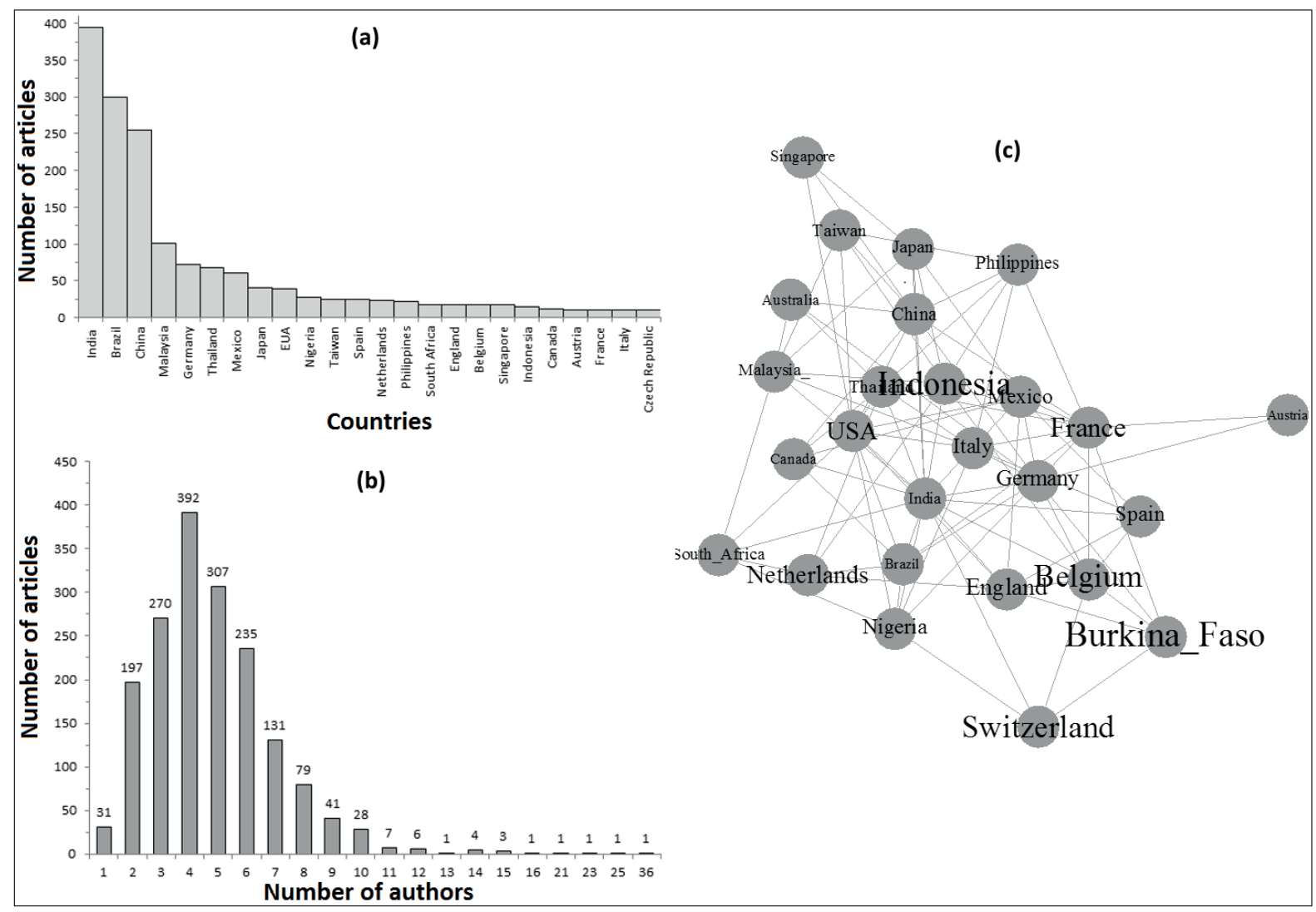


In Brazil, 15 thousand hectares were planted in 2008 (GEXSI, 2008). Despite an initial prediction of increased production (to nearly 12.8 million ha in 2015) the actual reality is very different. Nowadays, the Brazilian Association of Jatropha Producers (or ABPPM), founded in September 2007, is closed and $J$. curcas production on a large scale is nonexistent.

The results presented in this study show a contradiction: although the number of articles about J. curcas has increased significantly over time, commercial interests and planted areas have decreased in recent years. The probable reasons include the high costs of implementation, maintenance, and harvest; the variation in oil quality and oil content present in seeds; the fruits ripening are not uniform; and the high incidence of pests and diseases (LAVIOLA; DIAS, 2008; RUBIO et al., 2013; VERONESI et al., 2012). In addition, most forms of $J$. curcas are toxic, making the seed unsuitable for use as a livestock feed; it also presents a human safety hazard. In addition to those drawbacks, the average financial remuneration offered to household physic nut farmers by refineries is very low.

Overall, the Brazilian knowledge of the cultivar is extremely limited and there is an evident need to develop new research projects. The Empresa Brasileira de Pesquisa Agropecuária (EMBRAPA) has continued to research Jatropha because it is a promising species, but years of research will be needed for it to become a commercial reality. At present, there is little information about breeding programs, forms of propagation and planting, or the establishment of management systems, in particular involving the treatment of pests and diseases on commercial plantations and harvesting techniques.

In the future, perhaps $J$. curcas will provide some of the biofuel produced commercially in Brazil. This country sets a good example in the area of biofuel use, as the Brazilian government uses tax exemptions as a policy instrument to promote biofuels. For example, Law $n^{\circ} 13.033$, enacted on
September 24, 2014 established the mandatory addition of $7 \%$ biodiesel to diesel oil sold to consumers across the country. Despite this high incentive to encourage biodiesel production, very little biodiesel has been extracted from $J$. curcas.

Research cooperation has been evaluated using average authorship levels and collaboration networks. Figure 4B shows that most articles were written by $2-8$ authors. Figure $4 \mathrm{C}$ shows the international collaboration network linking authors from different countries. The countries with the highest number of collaborative projects were: Burkina Faso, Belgium, Indonesia, Switzerland, and the USA. In science, international collaborations tend to increase when there is a convergence of issues of common interest. However, there are frequently conflicts of interest when the themes involve commercial business; in such cases, the number of collaborators per article tends to be low.

\section{Conclusion}

To summarize the results of this study, the scientometric approaches used in this work have revealed a continuous increase in both quantitative and qualitative parameters in physic nut studies. The main trends in $J$. curcas studies relate to biofuel production and agronomic characteristics. Our analysis found little information about forestry and sustainability, animal nutrition, or genetic improvement. Another problem identified in this study was a lack of commercial seeds, which none of the studies used. In relation to scientific production, India, Brazil, and China together were responsible for $55 \%$ of the knowledge obtained about this species. Moderate levels of international collaboration were observed between countries, perhaps as consequence of conflicts of interest. Despite the increase in the number of articles about $J$. curcas, there is a decrease in worldwide crop production. 


\section{Acknowledgments}

The authors would like to thank the following Research Funding Agencies: FAPEG, CNPq, FNDCT, CAPES, and FINEP. We are also grateful to the Research and Scientific Production Support Program (PROBIP/UEG) of the Universidade Estadual de Goiás. JCN, PJG were supported by productivity fellowships of Conselho Nacional de Desenvolvimento Científico e Tecnológico (CNPq).

\section{References}

ACHTEN, W. J. M.; NIELSEN, L. R.; AERTS, R.; LENGKEEK, A. G.; KJÆR, E. D.; TRABUCCO, A.; HANSEN, J. K.; MAES, W. H.; GRAUDAL, L.; AKINNIFESI, F. K.; MUYS, B. Towards domestication of Jatropha curcas. Biofuels, London, v. 1, n. 1, p. 91107, 2010.

BAILIS, R.; MCCARTHY, H. Carbon impacts of direct land use change in semiarid woodlands converted to biofuel plantations in India and Brazil. GCB Bioenergy, Hoboken, v. 3, n. 6, p. 449-460, 2011.

BEHERA, S. K.; SRIVASTAVA, P.; TRIPATHI, R.; SINGH, J. P.; SINGH, N. Evaluation of plant performance of Jatropha curcas L. under different agropractices for optimizing biomass - a case study. Biomass and Bioenergy, Oxford, v. 34, n. 1, p. 30-41, 2010.

BHERING, L. L.; BARRERA, C. F.; ORTEGA, D.; LAVIOLA, B. G.; ALVES, A. A.; ROSADO, T. B.; CRUZ, C. D. Differential response of Jatropha genotypes to different selection methods indicates that combined selection is more suited than other methods for rapid improvement of the species. Industrial Crops and Products, Amsterdam, v. 41, n. 1, p. 260-265, 2013.

BRITTAINE, R.; LUTALADIO, N. Jatropha: a smallholder bioenergy crop - the potential for pro-poor development. In: . Integrated crop management. Rome: Food and Agriculture Organization of the United Nations, FAO, 2010. v. 8, 96 p.

CONTRAN, N.; CHESSA, L.; LUBINO, M.; BELLAVITE, D.; ROGGEROA, P. P.; ENNEA, G. Stateof-the-art of the Jatropha curcas productive chain: from sowing to biodiesel and by-products. Industrial Crops and Products, Oxford, v. 42, n. 1, p. 202-215, 2013.

CSARDI, G.; NEPUSZ, T. The igraph software package for complex network research. Intern Journal Complex Systems, Kassel and Würzburg, v. 1, n. 1695, p. 1-9, 2006.
DEBNATH, M.; BISEN, P. S. Jatropha curcas L. a multipurpose stress resistant plant with a potential for ethnomedicine and renewable energy. Cur Pharm Biotech, Germany, v. 9, n. 4, p. 288-306, 2008.

DEVAPPA, R. K.; RAJESH, S. K.; KUMAR, V.; MAKKAR, H. P. S.; BECKER, K. Activities of Jathropha curcas phorbol esters in various bioassays. Ecotoxicology and Environmental Safety, New York, v. 78 , n. 1, p. 57-62, 2012.

DIAS, L. A. S.; MISSIO, R. F.; DIAS, D. C. F. S. Antiquity, botany, origin and domestication of Jatropha curcas (Euphorbiaceae), a plant species with potential for biodiesel production. Genetics and Molecular Research, Ribeirão Preto, v. 11, n. 3, p. 2719-2728, 2012.

FREITAS, R. G.; DIAS, L. A.; CARDOSO, P. M.; EVARISTO, A. B.; SILVA, M. F.; ARAÚJO, N. M. Diversity and genetic parameter estimates for yield and its components in Jatropha curcas L. Genetics and Molecular Research, Ribeirão Preto, v. 24, n. 15, p.1-10, 2016.

FREITAS, R. G.; MISSIO, R. F.; MATOS, F. S.; RESENDE, M. D.; DIAS, L. A. Genetic evaluation of Jatropha curcas: an important oilseed for biodiesel production. Genetics and Molecular Research, Ribeirão Preto, v. 10, n. 3, p. 1490-1498, 2011.

GLOBAL EXCHANGE FOR SOCIAL INVESTMENT - GEXSI LLP. Global market study on Jatropha. London/ Berlin: Latin America (WWF), 2008. (Project inventory).

JONGSCHAAP, R. E. E.; CORR'E, W. J.; BINDRABAN, P. S.; BRANDENBURG, W. A. Claims and facts on Jatropha curcas L. Global Jatropha curcas evaluation, breeding and propagation programme. Wageningen: Plant Research International, 2007. 42 p. (Report, 158).

KOSCHÜTZKI, D.; SCHREIBER, F. Centrality analysis methods for biological networks and their application to gene regulatory networks. Gene Regul Syst Bio, Thousand Oaks, v. 15, n. 2, p. 193-201, 2008.

LAVIOLA, B. G.; ALVES, A. A.; KOBAYASHI, A. K.; FORMIGHIERI, E. F. Pinhão manso na EMBRAPA Agroenergia. Brasília: INFOTECA-E, 2015. 7 p. (Comunicado técnico, n. 12).

LAVIOLA, B. G.; DIAS, L. A. S. Nutrient concentration in Jatropha curcas L. leaves and fruits and estimated extraction at harvest. Revista Brasileira de Ciência do Solo, Viçosa, v. 32, n. 5, p. 1969-1975, 2008.

MAKKAR, H. P. S.; BECKER, K.; SPORER, F.; WINK, M. Studies on nutritive potential and toxic constituents of different provenances of Jatropha curcas. Journal of Agricultural Food Chemistry, Washington, v. 45, n. 8, p. 3152-3157, 1997. 
MENDONÇA, S.; LAVIOLA, B. G. Uso potencial e toxidez da torta de pinhão-manso. Brasília: EMBRAPA Agroenergia, 2009. 8 p. (Comunicado técnico, 1).

MUND, M.; KLOFT, B.; BUNDSCHUH, M.; KLINGELHOEFER, D.;GRONEBERG, D. A.; GERBER, A. Global research on smoking and pregnancy: a scientometric and gender analysis. Int $J$ Environ Res Public Health, Basel, v. 11, n. 6, p. 5792-5806, 2014.

R CORE TEAM - R: a language and environment for statistical computing. Vienna: R Foundation for Statistical Computing, 2013. Available at: <http://www.R-project. org/>. Access at: 05 june 2017.

RAHEMAN, H.; PADHEE, D. Bio-electricity generation using Jatropha oil seed cake. Recent Patents Biotechnology, Athens, v. 10, n. 3, p. 79-85, 2016.

ROCHA, R. B.; RAMALHO, A. R.; TEIXEIRA, A. L.; LAVIOLA, B. G.; SILVA, F. C. G.; MILITÃO, J. S. L. T. Eficiência da seleção para incremento do teor de óleo do pinhão-manso. Pesquisa Agropecuária Brasileira, Brasília, v. 47, n. 1, p. 44-50, 2012.

RUBIO, F.; MENEGHEL, A. P.; GOMES, L. F. S.; MALAVASI, M. D. Stages of maturation of the fruit on germination and oil content in seeds of Jatropha curcas Lin. Semina: Ciências Agrárias, Londrina, v. 34, n. 2, p. 663-668, 2013.

SHABANIMOFRAD, M.; RAFII, M. Y; MEGAT WAHAB, P. E; BIABANI, A. R.; LATIF, M. A. Phenotypic, genotypic and genetic divergence found in 48 newly collected Malaysian accessions of Jatropha curcas L. Industrial Crops and Products, Amsterdam, v. 42, n. 6, p. 543-551, 2013.
SHAHINUZZAMAN, M.; YAAKOB, Z.; MONIRUZZAMAN, M. Medicinal and cosmetics soap production from Jatropha oil. Journal Cosmetic Dermatology, Medford, v. 15, n. 2, p. 185-193, 2016.

SHARMA, A. K.; GANGWAR, M.; KUMAR, D.; NATH, G.; KUMAR SINHA, A. S.; TRIPATHI, Y. B. Phytochemical characterization, antimicrobial activity and reducing potential of seed oil, latex, machine oil and press cake of Jatropha curcas. Avicenna Journal of Phytomedicine, Mashhad, v. 6, n. 4, p. 366-375, 2016.

THOMAS, R.; SAH, N.; SHARMA, P. Therapeutic biology of Jatropha curcas: a mini review. Current Pharmaceutical Biotechnology, Hilversum, v. 9, n. 4, p. 315-324, 2008.

VERONESI, C. D.; SOUZA, C. M. A. de; SERRA, A. P.; RAFULL, L. Z. L.; SILVA, C. J. da; ROS, V. D. Economical feasibility of the harvesting and the processing of Jatropha curcas L. seeds in different stage of maturation. Semina: Ciências Agrárias, Londrina, v. 33, n. 6, p. 2047-2056, 2012.

VITZTHUM, K.; SCUTARU, C.; MUSIAL-BRIGHT, L.; QUARCOO, D.; WELTE, T.; SPALLEK, M.; GRONEBERG-KLOFT, B. Scienciometric analysis and combined density-equalizing mapping of environmental tobacco smoke (EST) research. PLoS One, San Francisco, v. 5, n. 6, p. e11254, 2010 .

YU, G.; LI, Y. J. Parameter identification of the observed citation distribution. Scientometrics, Amsterdam, v. 71, n. 2, p. 339-348, 2007. 
